\title{
A multistep procedure to prepare pre-vascularized cardiac tissue constructs using adult stem sells, dynamic cell cultures, and porous scaffolds
}

\author{
Stefania Pagliari ${ }^{1,2}$, Annalisa Tirella ${ }^{3,4}$, Arti Ahluwalia ${ }^{3,4}$, Sjoerd Duim ${ }^{5}$, Marie-Josè Goumans ${ }^{5}$, \\ Takao Aoyagi ${ }^{1 *}$ and Giancarlo Forte ${ }^{1,2 *}$ \\ ' Biomaterials Unit, International Center for Materials Nanoarchitectonics, National Institute for Materials Science, Tsukuba, Japan \\ 2 International Clinical Research Center, Integrated Center of Cellular Therapy and Regenerative Medicine, St. Anne's University Hospital, Brno, Czech Republic \\ ${ }^{3}$ Interdepartmental Research Center "E. Piaggio," University of Pisa, Italy \\ 4 Institute of Clinical Physiology, National Research Council (CNR), Pisa, Italy \\ ${ }^{5}$ Department of Molecular Cell Biology, Leiden University Medical Center, Leiden, Netherlands
}

\section{Edited by:}

Valentina Di Felice, University of

Palermo, Italy

Reviewed by:

Teun P. De Boer, University Medical

Center Utrecht, Netherlands

Marcin Wysoczynski, University of

Louisville, USA

*Correspondence:

Takao Aoyagi, Smart Biomaterials Group, International Center for

Materials Nanoarchitectonics,

National Institute for Materials

Science, 1-1 Namiki, Tsukuba,

Ibaraki 305-0051, Japan

e-mail: aoyagi.takao@nims.go.jp;

Giancarlo Forte, International Clinical

Research Center, Integrated Center

of Cellular Therapy and

Regenerative Medicine, St. Anne's

University Hospital, Pekarska 53 ,

65691 Brno, Czech Republic

e-mail: giancarlo.forte@fnusa.cz
The vascularization of tissue engineered products represents a key issue in regenerative medicine which needs to be addressed before the translation of these protocols to the bedside can be foreseen. Here we propose a multistep procedure to prepare pre-vascularized three-dimensional (3D) cardiac bio-substitutes using dynamic cell cultures and highly porous biocompatible gelatin scaffolds. The strategy adopted exploits the peculiar differentiation potential of two distinct subsets of adult stem cells to obtain human vascularized 3D cardiac tissues. In the first step of the procedure, human mesenchymal stem cells (hMSCs) are seeded onto gelatin scaffolds to provide interconnected vessel-like structures, while human cardiomyocyte progenitor cells (hCMPCs) are stimulated in vitro to obtain their commitment toward the cardiac phenotype. The use of a modular bioreactor allows the perfusion of the whole scaffold, providing superior performance in terms of cardiac tissue maturation and cell survival. Both the cell culture on natural-derived polymers and the continuous medium perfusion of the scaffold led to the formation of a densely packaged proto-tissue composed of vascular-like and cardiac-like cells, which might complete maturation process and interconnect with native tissue upon in vivo implantation. In conclusion, the data obtained through the approach here proposed highlight the importance to provide stem cells with complementary signals in vitro able to resemble the complexity of cardiac microenvironment.

Keywords: cardiac tissue engineering, adult stem cells, vascularized three-dimensional (3D) scaffolds, dynamic culture, patient-derived stem cells

\section{INTRODUCTION}

The successful regeneration of injured areas of the myocardium by tissue-engineered constructs relies on the long time viability and persistence of the bio-substitute in vivo, given the harsh conditions cells in the infarcted milieu are exposed to. Previous investigations revealed the sudden disappearance of cells administered by injection — systemically or locally-independent of cell type. This negative outcome has been ascribed to the low retention and high mortality of cells in the hypoxic environment characterized by an inflammatory response and the lack of local blood supply (Gnecchi et al., 2008; Menasche, 2011). The issue of promoting ischemic area vascularization has been lately addressed by cardiac tissue engineers through different approaches: (i) the administration of pro-angiogenic factors supplied by direct injection or through drug-releasing carriers (Sato et al., 2001; Chiu and Radisic, 2010; Singh et al., 2012); (ii) the infusion of endothelial progenitors (EPCs) or mature endothelial cells (ECs; Lian et al., 2008); and (iii) the pre-vascularization of the tissue constructs produced in vitro before implantation (Caspi et al., 2007; Dvir et al., 2009). Although the first two strategies are potentially interesting in a therapeutic perspective, they rely on the in situ generation and organization of vascular structures which depend either on the bioavailability of beneficial molecules or on the growth and differentiation capacity of vascular cells or their progenitors (Lovett et al., 2009). The early clinical trials in which growth factors or cells were delivered to the injured heart yielded disappointing results in terms of improvement of cardiac function (Urbich et al., 2005; Dubois et al., 2010; Simón-Yarza et al., 2012). The pre-vascularization of cardiac patches is also appropriate for providing a capillary network to support cells in the inner core of the implant, while biocompatible substrates are deemed to contribute to the improvement of retention and engraftment of the transplanted cardiac tissue (Terrovitis et al., 2010; Segers and Lee, 2011). The advantage of the pre-vascularization of thick muscle constructs was underlined by the demonstration that cocultures including skeletal myoblasts, endothelial cells (or their progenitors) and embryonic fibroblasts on biocompatible porous scaffolds can enhance the overall survival and functionality of the constructs in vivo (Levenberg et al., 2005). Moreover, the adoption of scaffolds displaying an interconnected porosity itself 
could foster host vascular cell recruitment, with the possibility of vessels branching throughout the core of the construct. Alternatively, scaffoldless thick cardiac constructs were provided with a vascular bed (Sekine et al., 2013), or with microchannels (Sakaguchi et al., 2013) to favor vessel ingrowth, although biocompatible supports improve the handling of the grafts and can provide cells with appropriate bio-mechanical signals to better induce tissue regeneration and repair. In this context, the use of porous gelatin scaffolds represents a suitable tool for cardiac tissue engineering application (Sakai et al., 2001; Akhyari et al., 2002). In fact, gelatin is a cheap polymer derived from collagen denaturation and hydrolysis, and, due to its natural origin, it displays excellent cell adhesion property ( $\mathrm{Wu}$ et al., 2011). It also features high biocompatibility, low immunogenicity, and biodegradability (Xing et al., 2014). In addition, gelatin sponges have been proven effective in inducing angiogenesis (Dreesmann et al., 2007) and their porous structure can favor the vascularization of the construct by supporting the diffusion of cells and nutrients within its core area. Its mechanical properties can be easily adjusted to match those encountered in living tissues.

The use of autologous stem cells has been proposed for various cell therapy applications as a mean to avoid the immune rejection issues raised by allogeneic or xenogeneic derivatives and the ethical concerns due to the use of embryonic material. Human bone marrow-derived mesenchymal stem cells (hMSCs) are an excellent candidate for regenerative medicine applications due to their autologous origin, their immunomodulatory properties and relative safety in clinical practice (Lalu et al., 2012). The in vitro multilineage differentiation potential of mesodermal progenitors has been proven in a number of studies (Pittenger et al., 1999; Muraglia et al., 2000) and their ability to express endothelial markers upon growth factor stimulation (Oswald et al., 2004; Jazayeri et al., 2008; Portalska et al., 2012) and response to bio-mechanical stimulation (stretching, shear stress, substrate mechanical properties tuning; Lozito et al., 2009; Bai et al., 2010) has been shown. More importantly, the benefits of MSC-based therapy have mainly been ascribed to their ability to generate endothelial cells and exert pro-angiogenic and cardioprotective effects by paracrine mechanisms rather than to direct the generation of new contractile cells (Gnecchi et al., 2008; Meyer et al., 2009; Wöhrle et al., 2010; Loffredo et al., 2011).

Among the adult stem cell subsets so far proposed for cardiac muscle repair, resident cardiac stem/progenitor cells (CSCs or CPCs) were shown to retain the ability to differentiate into all the cardiac tissue cell types (Beltrami et al., 2003; Forte et al., 2011) and favor cardiac healing by direct production of contractile cells in vivo (Smits et al., 2009a,b).

By taking advantage of the peculiar differentiation potential of hMSCs and human cardiomyocyte progenitor cells (hCMPCs), in the present investigation we propose a multistep procedure to obtain human pre-vascularized three-dimensional (3D) cardiac bio-substitutes based on highly porous gelatin scaffolds displaying the stiffness of cardiac tissue. Given the thickness and the dimensions of the bio-construct, a modular dynamic culture system has been used to guarantee scaffold perfusion and promote cell colonization of the inner layers.
Although being here tested exclusively in vitro, the present method allows for the formation of a 3D cardiac construct based on a physiological environment given by the gelatin scaffold and featuring the use of autologous stem cells with unique potential.

\section{MATERIALS AND METHODS PREPARATION OF POROUS GELATIN SCAFFOLDS}

All materials used (unless specified) were purchased from SigmaAldrich (Italy). A 5\% w/v gelatin solution was prepared by dissolving gelatin (Type A, G1890, 300 bloom strength) in deionized water. Porous gelatin scaffolds were prepared with a multi-step procedure. The solution was stirred for $1 \mathrm{~h}$ at $50^{\circ} \mathrm{C}$, allowing complete dissolution, then casted in cylindrical shaped mold and physically gelled at room temperature. Samples were kept at $4^{\circ} \mathrm{C}$ for $1 \mathrm{~h}$, and then at $-20^{\circ} \mathrm{C}$ overnight. Gelatin samples were then freeze-dried $\left(-50^{\circ} \mathrm{C}, 150 \mathrm{mBar}\right)$ to obtain a porous structure as described elsewhere (Lien et al., 2009). Samples were swollen in deionized water and then cross-linked by immersion in a $10 \mathrm{mM}$ glutaraldehyde (GTA) solution in $40 \% \mathrm{v} / \mathrm{v}$ ethanol/deionized water. The crosslinking reaction was controlled by keeping the glutaraldehyde/gelatin ratio (defined as molar concentration of GTA versus gelatin weight) constant. The scaffolds were immersed in GTA solution at $4^{\circ} \mathrm{C}$ for $48 \mathrm{~h}$, until the crosslinking reaction occurred. Therefore, the samples were immersed in $0.1 \mathrm{M}$ glycine solution in deionized water for $2 \mathrm{~h}$ at room temperature in order to stop any further cross-linking reaction (and remove any excess of GTA). Phosphate buffered solution (PBS) was sequentially used to rinse samples. Samples were kept at $-20^{\circ} \mathrm{C}$ overnight, and finally freeze-dried $\left(-50^{\circ} \mathrm{C}, 150 \mathrm{mBar}\right)$ until all water content was removed. Samples were then stored at room temperature and sterilized with gas plasma before using.

\section{SCAFFOLD MECHANO-ARCHITECTURAL PROPERTIES: SWELLING, POROSITY, AND STIFFNESS}

Water absorption capability, porosity and stiffness of the porous gelatin scaffolds were evaluated using the procedure described elsewhere (Spinelli et al., 2012). Swelling ratio (Q) was calculated from the ratio of the weight of a dry $\left(W_{0}\right)$ and a completely swollen $\left(W_{\text {eq }}\right)$ sample (Brannon-Peppas and Peppas, 1990) returning the amount of adsorbed water. For the measurements, cryogel were swollen in deionized water at room temperature and weighted $\left(W_{\mathrm{i}}\right)$ at different time points until a swelling equilibrium was reached. A precision microbalance (AE240, Mettler, Italy) was used: in case of wet samples, blotting paper was used to remove the water in excess. Porosity was indirectly evaluated by the imbibition method (Mwangi and Ofner, 2004; Martucci et al., 2006), while pore size was directly measured by processing both Scanning Electron Microscopy (SEM) and optical microscopy acquisition of sample sections with ImageJ (Abramoff et al., 2004). Sample stiffness was measured by compressive mechanical tests. Prior to the tests, samples were completely swollen in deionized water, compressive tests were then performed using a Zwick-Roell Z005 Instron twin column-testing machine (Zwick Testing Machines Ltd., UK). Samples were compressed up to $5 \%$ of their initial length using a $0.01 \mathrm{~mm} \cdot \mathrm{s}^{-1}$ strain rate; tests were performed with the samples partially immersed in water to preserve their hydration. Data were then post-processed 
and stress-strain curves were obtained. Samples stiffness was evaluated within $1 \%$ strain (first linear zone) of the stress-strain curve.

\section{BIOREACTOR WORKING CONDITIONS}

A computational fluid-dynamic (CFD) analysis of the modular chamber bioreactor with a porous scaffold was performed, assessing the perfusion and oxygenation of the millimeter sized scaffold. The analysis was performed using Brinkman and Incompressible Navier-Stokes equations were combined with reaction and diffusion equations using Comsol Multiphysics (COMSOL AB, Stockholm, Sweden). The system was then modeled with a porous domain representing the scaffold (porous section of $2 \times 12 \mathrm{~mm}$ in size, with permeability of $1.68 \times 10^{-10} \mathrm{~m}^{2}$ and $90 \%$ porosity) placed on the bottom of the bioreactor perfusion chamber, which is represented by a fluid domain. A preliminary analysis was performed in order to verify scaffold oxygenation as function of bioreactor flow rate (Supplementary Figure 1A). Chosen an inner flow rate to a value of $200 \mu \mathrm{L} / \mathrm{min}$, fluid flow inside the perfusion chamber and scaffold's perfusion was analyzed (Supplementary Figure 1B).

\section{CELL CULTURE}

hMSCs were purchased from Lonza and cultured in MSCGM ${ }^{\mathrm{TM}}$ BulletKit $^{\mathrm{TM}}$ (hMSC basal medium, Lonza Japan Ltd, Tokyo, Japan). The cells were expanded to the desired number and used between passages 3 and 7 . For the endothelial differentiation in 2D conditions, hMSCs were seeded onto tissue culture polystyrene plates (TCPS) and cultured for 7 days in endothelial differentiation medium [(EDM: hMSC basal medium supplemented with $50 \mathrm{ng} / \mathrm{ml}$ VEGF165 (R\&D systems)]. hCMPCs were isolated from healthy donor atrial biopsies, cultured in basal medium (M199/EGM-2 (Lonza) (3:1) 10\% FBS (Equitech-Bio Inc., Kerrville, Texas, USA), 1\% MEM nonessential amino acids (from $50 \times$ stock; Life Technologies Gaithersburg, Maryland, USA) and 2\% penicillin/streptomycin (from 50× stock; Invitrogen, Carlsbad, California, USA) and differentiated in cardiac differentiation medium (CDM: IMDM/Hams F12 (1:1, Life Technologies) with L-glutamine (Life Technologies), 2\% horse serum (Life Tchnologies), nonessential amino acids, insulin-transferrin-selenium (Invitrogen), penicillin/streptomycin) as previously described (Smits et al., 2009a,b). Briefly, minced auricle were digested in collagenase A $(1 \mathrm{mg} / \mathrm{ml})$ for $2 \mathrm{~h}$ at $37^{\circ} \mathrm{C}$ while stirring. Afterwards, the solution was filtered through $40-\mu \mathrm{m}$ cell strainer and centrifuged at $300 \mathrm{~g}$ for $5 \mathrm{~min}$ at RT. Then, the pellet was resuspended in cold buffer containing EDTA ( $2 \mathrm{mM}$ ) and 2\% FBS and filtered through $40-\mu \mathrm{m}$ cell strainer. The filtered cell population was subjected to magnetic cell sorting (Miltenyi Biotec, Sunnyvale, CA, USA) using Sca-1-coupled beads, following the manufacturer's proto$\mathrm{col}$, in order to isolate Sca-1-like + progenitor cells. The cells were cultured on $0.1 \%$ gelatin- (Sigma-Aldrich, St Louis, Missouri, USA) coated plates in basal medium. For cardiac differentiation, cells were grown in differentiation medium supplemented with $5 \mu$ M 5-azacytidine (Wako Pure Chemical Industries, Ltd, Osaka, Japan) for $72 \mathrm{~h}$. After induction, the medium was replaced with differentiation medium supplemented with $10^{-4} \mathrm{M}$ ascorbic acid
(Wako) and TGF- $\beta 1$ ( 1 ng/ml, PeproTech, Rocky Hill, NJ, USA) and changed every 3 days for up to 3 weeks. Human umbilical vein endothelial cells (HUVEC) were purchased from Lonza, grown in EGM-2 bullet kit media and used between passage 2 and 4 . The media were replenished every other day.

\section{GENERATION OF TNT-GFP hCMPCs}

The pGreenZeo lentiviral expression vector carrying the fulllength copGFP gene under the control of cardiac Troponin $\mathrm{T}$ type 2 (TNNT2) promoter was purchased from SBI (System Biosciences Inc. Mountain View, CA, USA) and delivered into mammalian cells according to the manufacturer's instructions. Briefly, hCMPCs were transduced at an approximate MOI of 20 and incubated at $37^{\circ} \mathrm{C}$ overnight. The following day, half of the culture medium was replaced with fresh medium and $48 \mathrm{~h}$ after the transduction, the medium was discarded and fresh medium added. The cells (hereafter referred as cTNT-GFP hCMPCs) were cultured on TCPS or gelatin scaffolds in the presence of basal medium or CDM.

\section{CELL SEEDING AND 3D DISTRIBUTION IN GELATIN SCAFFOLDS}

Prior to cell seeding, gelatin scaffolds were swollen in cell culture medium in Ultra-low Attachment 24-well plates (Corning ${ }^{\circledR}$ Incorporated) for $24 \mathrm{~h}$. The cells $\left(2.0 \times 10^{5}\right)$ were directly seeded on top of each scaffold in a small volume $(100 \mu \mathrm{l})$ of appropriate medium and allowed to adhere for $60 \mathrm{~min}$ before adding the rest of medium. Then, the scaffolds were placed in the incubator for $12 \mathrm{~h}$ and transferred in another low-adhesion well. Cardiac TNTGFP hCMPCs were cultured into scaffolds for 7 days in complete hCMPCs basal medium or CDM, while hMSCs-seeded scaffolds were cultured for 4 days in a mixture of Matrigel ${ }^{\mathrm{TM}} / \mathrm{hMSC}$ basal medium (1:10) with or without VEGF $(50 \mathrm{ng} / \mathrm{mL}$ ) before being processed or co-cultured with pre-conditioned cardiac progenitors. The formation of vascular-like structures on gelatin scaffolds was followed by labeling hMSCs with the membrane-permeable live-cell labeling dye Calcein AM (Invitrogen) after 4 days of culture in EDM. Briefly, Calcein AM was added to hMSC-seeded scaffolds at a final concentration of $2 \mu \mathrm{M}$ for $30 \mathrm{~min}$ at $37^{\circ} \mathrm{C}$ and $5 \% \mathrm{CO}_{2}$ in the dark. Five scaffolds have been used for any single experiment. The experiments have been performed independently three times.

\section{DYNAMIC CULTURE}

A commercial modular chamber bioreactor (Quasi-Vivo ${ }^{\circledR}$, QV500, Kirkstall, United Kingdom) was used to perfuse the scaffolds. The main feature of this system is the ability to apply high flow rates and provide high nutrient turnover to cells without imposing high shear stress or turbulent flow (Mazzei et al., 2010). Pre-seeded scaffolds were gently transferred into the bioreactor chamber, and then the chamber was filled with cell culture media prior to perfusion. Two Quasi-Vivo ${ }^{\circledR}$ chambers and one mixing chamber (growth medium reservoir) were then connected in series to a peristaltic pump (High Performance Perista BIO-MINI PUMP, ATTO) giving a final volume of cell culture media of about $21 \mathrm{~mL}$. The use of the mixing chamber guarantees medium oxygenation (Figure 1). To establish the optimal flow rate, the gelatin porous scaffold was included in the fluid-dynamic and oxygen 


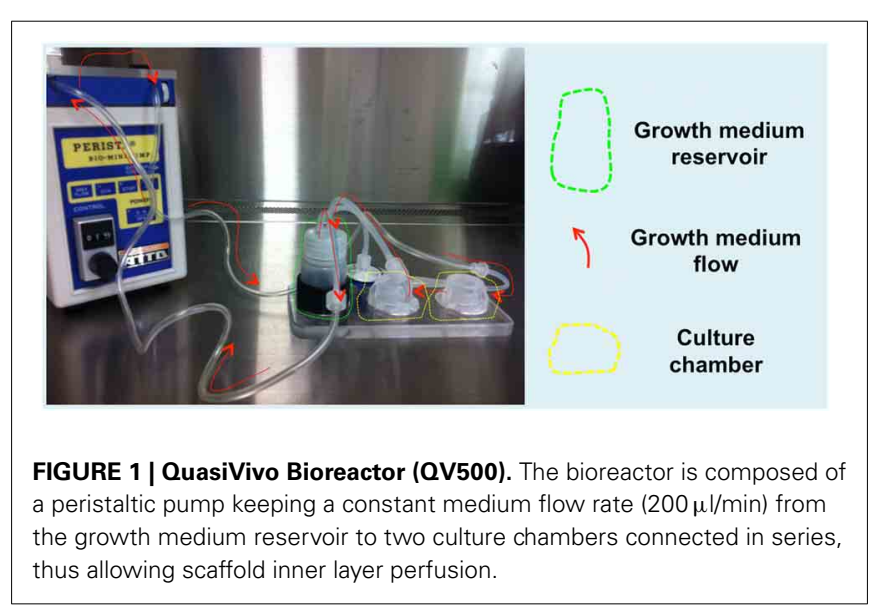

transport model previously described (Mazzei et al., 2010), giving consistent results (Supplementary Figure 1). Cardiac TNT-GFP hCMPCs grown for 7 days onto gelatin scaffolds in the bioreactor were used to study the effect of dynamic culture conditions on cell growth, differentiation potential and gene expression profile. The medium was replenished every third day. For the generation of vascularized cardiac grafts, scaffolds were soaked for $12 \mathrm{~h}$ in diluted Matrigel $^{\mathrm{TM}}$ (1:10 in hMSC basal medium) and switched to a new low-adhesion plate in EDM. The preconditioned scaffold was loaded with $2.0 \times 10^{5} \mathrm{hMSCs}$ and kept for 4 days in the incubator at $37^{\circ} \mathrm{C}, 5 \% \mathrm{CO}_{2}$. After a 2 week pre-conditioning passage in CDM on TCPS, $2.0 \times 10^{5}$ cTNTGFP hCMPCs were seeded onto the vascularized scaffold and allowed to attach for $24 \mathrm{~h}$. Thence, the cell-loaded scaffolds were carefully moved to Quasi-vivo bioreactor chambers and perfused with CDM at $200 \mu \mathrm{l} / \mathrm{min}$ (the rate suggested by the computational model) for 7 days. Cells grown on TCPS and 3D scaffolds under static conditions were used as controls. Five scaffolds have been used for any single experiment. The experiments have been performed independently three times.

\section{REAL-TIME QUANTITATIVE PCR ANALYSIS}

Total RNA was extracted by TRIZOL ${ }^{\circledR}$ Reagent according to the manufacturer's instructions (Invitrogen). One microgram of RNA for each sample, measured by NanoDrop 2000 (Thermo Scientific) and assessed on ReadyAgarose Precast Gel (Bio-Rad), was retro-transcribed using $\mathrm{RT}^{2}$ First Strand Kit including DNAse treatment to remove genomic DNA (SA Biosciences Corp., USA). The resulting cDNA was diluted 1:10 in DNase/RNasefree water and the expression profile of genes involved in different pathways analyzed by the following $\mathrm{RT}^{2}$ Profiler $^{\mathrm{TM}}$ PCR Arrays (SA Biosciences Corp.): (i) $\mathrm{RT}^{2}$ Profiler ${ }^{\mathrm{TM}}$ PCR Array Human Angiogenesis (PAHS-024Z); (ii) $\mathrm{RT}^{2}$ Profiler $^{\mathrm{TM}}$ PCR Array Human Extracellular Matrix \& Adhesion Molecules (PAHS-013); (iii) qBiomarker iPSC PCR Array Cardiomyocytes differentiation (iPHS102); (for a comprehensive list of genes included in these arrays please refer to Supplementary Table 1). Real-time PCR was performed on ABI 7500 Real-Time PCR System (AB Applied Biosystems, Foster City, CA) using RT ${ }^{2}$ SYBR Green/ROX qPCR Master Mix (SA Biosciences Corp.) and the following cycling parameters: 1 cycle at $95^{\circ} \mathrm{C}$ for $10 \mathrm{~min} ; 40$ cycles at $95^{\circ} \mathrm{C}$ for $15 \mathrm{~s}$, and $60^{\circ} \mathrm{C}$ for $1 \mathrm{~min}$. Data was analyzed by the $\Delta \Delta \mathrm{Ct}$ method with the PCR Array Data Analysis Web Portal (http://www.SABiosciences.com/pcrarraydataanalysis.php). The graphs show the mean values of obtained fold changes by analyzing independently two samples per each experimental condition.

\section{STATISTICAL ANALYSIS}

Data are represented as mean \pm SD. Student's $T$-test was used to analyze the data. Comparisons between different conditions were considered statistically significant for $P<0.05$.

For a more extensive description of the Materials and Methods used, please refer to Supplementary Information.

\section{RESULTS \\ MODELING THE MULTI-DIMENSIONAL IN VITRO SYSTEM THROUGH GELATIN SCAFFOLDS DISPLAYING CARDIAC-LIKE MECHANICAL PROPERTIES}

Three dimensional gelatin scaffolds were characterized for their structure, water affinity, and stiffness. The analysis of the sections showed a distinctive bimodal pore size distribution. Although the average pore diameter ranged between 50-200 $\mu \mathrm{m}$ (with a few having a maximum size of $500 \mu \mathrm{m}$ ), the smaller pores were approximately double the size of the bigger pores (diameters of $61.62 \pm 24.01$ and $140.38 \pm 19.51 \mu \mathrm{m}$, respectively; Figure 2A). Swelling tests were performed to assess the scaffold capacity to retain water. The scaffolds were monitored over $24 \mathrm{~h}$ of immersion in cell culture media, showing a complete rehydration after $8 \mathrm{~h}$ with a swelling ratio of about $10.92 \pm 0.32$ (Figure 2B). These data were also used to measure scaffold porosity, which was found to be approximately 90\% (also confirmed in Spinelli et al., 2012). Finally, compressive mechanical tests were also performed on swollen samples (after $24 \mathrm{~h}$ in cell culture media), and on samples kept immersed in cell culture media and in the incubator for 1 week. Scaffold stiffness (evaluated within the first linear region of stress-strain plot, Figure 2C) was $10.5 \pm 1.4 \mathrm{kPa}$, which was stable in time. After scaffold characterization and assessment of mechano-architectural properties, attention was dedicated to define the most suitable working conditions of the bioreactors to guarantee a homogeneous scaffold oxygenation in the bioreactor. Specifically, literature values of hypoxic limits (1\%) (Cipolleschi et al., 1993) and oxygen consumption of stem cells $\left(K_{\mathrm{m}}=0.001 \mathrm{mM}, V_{\max }=1 \mathrm{pm} / \mathrm{min} / 10^{4}\right.$ cells) (Varum et al., 2011) were used to estimate the minimum oxygen concentration at the base of the scaffold as a function of flow rate and cell density, while the Wang and Tarbell approximation was used to calculate the shear stress at the pore walls. Results obtained from the computational models (reported in Supplementary Information) evidenced that-by using a flow rate of $200 \mu \mathrm{L} / \mathrm{min}$ - an oxygen concentration of $0.15 \mathrm{mM}$ at the base of the scaffold (14\%) and a shear stress of $1.10^{-6} \mathrm{~Pa}$ in the pores are obtained (Wang and Tarbell, 1995; Boschetti et al., 2006). The use of lower flow rates in the bioreactor may compromise oxygen supply rates to cells, especially as they proliferate, while higher flow rates may cause shear-related damage (Mazzei et al., 2010). Bioreactor parameters were set according to these results for all the following experiments. 


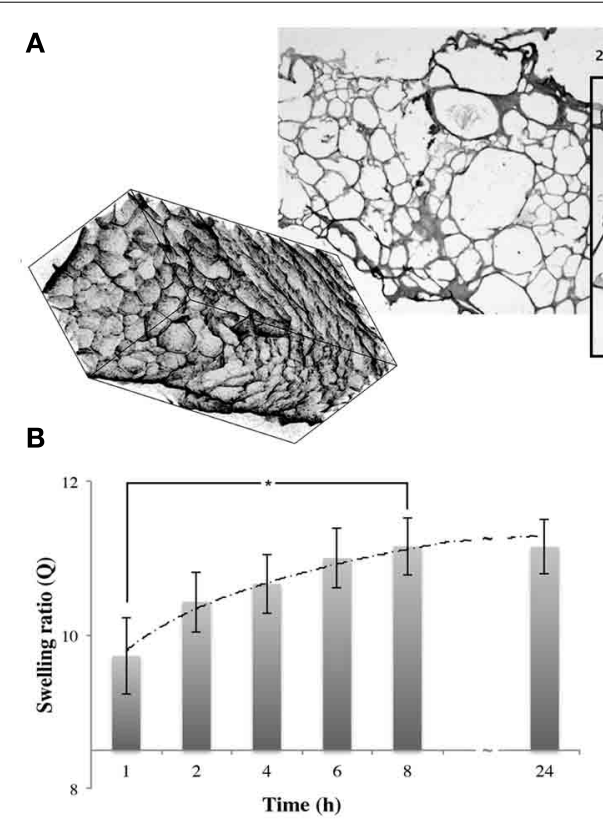

FIGURE 2 | The porous gelatin scaffold. Three-dimensional rendering of scaffold, brightfield images of scaffold section and pore dimension analysis (A). Modifications of swelling ratio of scaffold over $24 \mathrm{~h}$ in $\overline{200 \mu \mathrm{m}}$

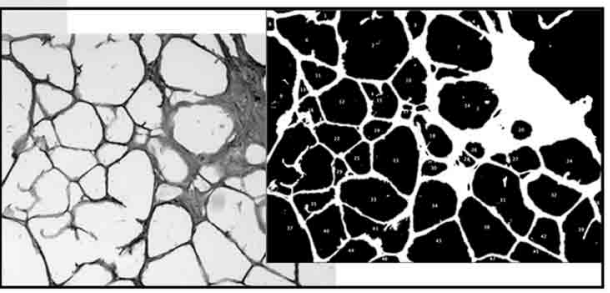

C

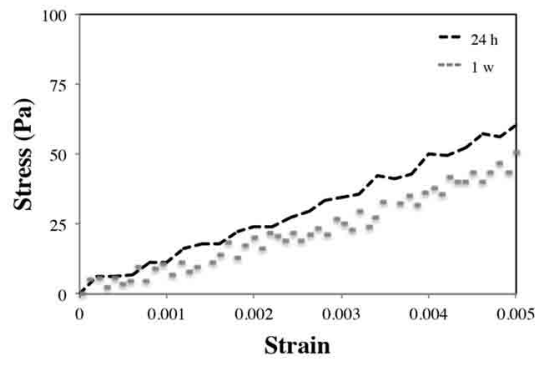

cell culture media (B). Stress-strain plot of gelatin samples (C) obtained after $24 \mathrm{~h}$ and 1 week in culture medium $\left(37^{\circ} \mathrm{C}, 5 \%\right.$ $\mathrm{CO}_{2}$ ). $* P<0.05$.

\section{D CULTURE INDUCES A GENERAL REMODELING IN THE EXPRESSION OF GENES INVOLVED IN CELL-MATRIX INTERACTION}

Establishing a physiologically relevant system requires the development of 3D culture conditions resembling the in vivo microenvironment (Pampaloni et al., 2007). As reported above, the scaffolds here used were designed to have mechanical properties similar to those of cardiac tissue (Engler et al., 2007). Preliminary experiments demonstrated that culturing human hCMPCs on 3D gelatin scaffolds for 7 days induced a clear upregulation in the expression of genes (fold change $\geq 2$, as compared to cells grown on TCPS) coding for proteins involved in cell-matrix remodeling (collagens (COL), laminins (LAMA), metalloproteinases (MMP) and their inhibitors (TIMP) and cell-cell adhesion (integrins) (Figure 3, for a complete list of the genes analyzed see Supplementary Table 1) and testified the actual activity of the cells in remodeling the scaffold.

\section{D POROUS GELATIN SCAFFOLDS REPRESENT A PERMISSIVE ENVIRONMENT FOR STEM CELL CARDIAC AND ENDOTHELIAL COMMITMENT}

The hCMPC reporter cell line (cTNT-GFP hCMPCs) was driven toward a cardiac phenotype in both 2D (Supplementary Figure 2) and 3D conditions, when stimulated with CDM (Figure 4A). Cell commitment was confirmed by the up-regulation of a number of cardiac-specific genes like actinin alpha 2 (ACTN2), adrenoceptor beta 1 (ADRB1), desmin (DES), cardiac troponin T type 2 (TNNT2), cardiac troponin I type 1 (TNNI1), myosin light chain (MYL) 2, 3, 7, myosin heavy chain b (MYH7) in cardiac progenitors stimulated on the scaffold as compared to their respective control (3D culture in basal medium). Moreover, when compared to cells cultured in CDM on TCPS, hCMPCs grown onto gelatin scaffolds encountered the up-regulation of few cardiac genes, confirming a superior performance of $3 \mathrm{D}$ vs. $2 \mathrm{D}$ culture conditions (Figure 4B, for a complete list of the genes analyzed see Supplementary Table 1). On the other hand, the ability of hMSCs to acquire an endothelial phenotype (Supplementary Figure 3) was exploited to obtain endothelial cells from hMSCs under 3D culture conditions. The scaffolds were treated with a mixture of EDM and Matrigel ${ }^{\mathrm{TM}}$ for $24 \mathrm{~h}$. SEM analysis showed that the interconnected porosity of the scaffold was not modified by Matrigel ${ }^{\mathrm{TM}}$ treatment (highlighted by yellow dotted line in Figure 4C) and that the successful adhesion of human cells was achieved (Figure 4C, right). Consequently, hMSCs grown on $3 \mathrm{D}$ gelatin scaffolds in EDM displayed the up-regulation of a wide range of angiogenic markers as compared to cells cultured on scaffolds in basal medium (Figure 4D, for a complete list of the genes analyzed see Supplementary Table 1). Confocal analysis of 3D scaffolds after 4 day hMSC culture demonstrated the establishment that cells loaded with Calcein AM or expressing endothelial marker VCAM-1 colonized the whole scaffold, while aligning around the pores (Figure 4E).

\section{DYNAMIC CULTURE CONDITIONS PROVIDE SUPERIOR PERFORMANCE IN TERMS OF CARDIAC COMMITTMENT OF hCMPCs}

The use of dynamic culture conditions using a bioreactor is thought to increase cell survival within a 3D structure by favoring inner core perfusion and catabolite removal (Cimetta et al., 2007; Burdick and Vunjak-Novakovic, 2009; Vozzi et al., 2011). Indeed, a slight although not significant increase in DNA content, indicative of cell proliferation, could be noticed 7 days after $3 \mathrm{D}$ cell culture in the bioreactor, as compared to static conditions (Figure 5A). Given the ability of human cardiac progenitor 

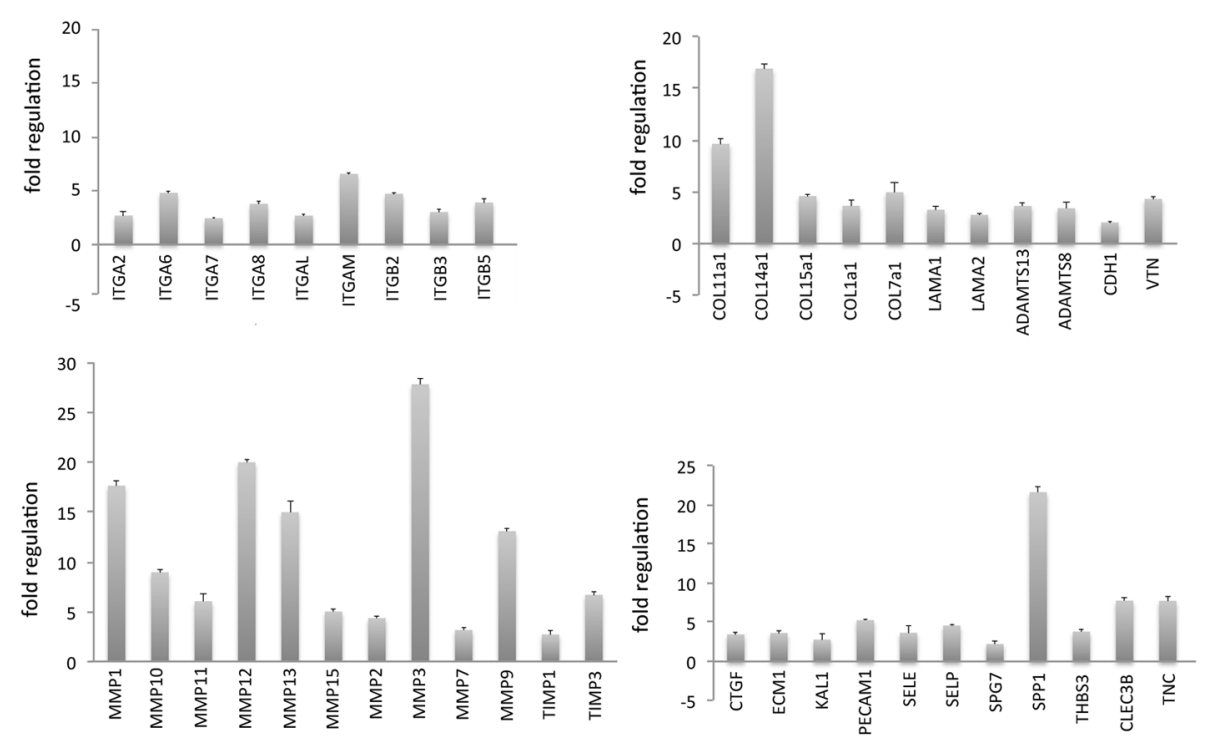

FIGURE 3 | Three-dimensional (3D) stem cell culture induces a significant remodeling in the expression of genes involved in cell adhesion and ECM deposition. Human cardiac progenitor cells (hCMPCs) were grown for
1 week on 3D gelatin scaffolds and the expression of 73 genes involved in cell-matrix interaction resulted upregulated, as evidenced by real time PCR (for a complete list of genes analyzed please refer to Supplementary Table1). cells to proceed to cardiac maturation on 3D gelatin scaffolds, their capacity to activate the cardiac program when exposed to dynamic conditions in a modular bioreactor was assessed. For this experiment, cTNT-GFP hCMPCs were pre-committed in CDM for 2 weeks on TCPS. Afterwards, an aliquot of this cell population was seeded onto scaffolds and further stimulated for 1 week under static or dynamic conditions. The data confirmed that the commitment of cTNT-GFP hCMPCs could be achieved by CDM in dynamic conditions (Figure 5B) and that a minor although significant spontaneous commitment of hCMPCs was induced by $3 \mathrm{D}$ culture conditions per se, as also described in static culture (white columns). Although the dynamic culture conditions did not significantly modify the percentage of GFP-positive cells with respect to the static protocol, real time PCR array analysis demonstrated that dynamic stimulation - when combined with differentiation medium - could lead to the up-regulation of few cardiac-specific genes (Figure 5C, for a complete list of the genes analyzed see Supplementary Table 1).

\section{GENERATION OF 3D PRE-VASCULARIZED CARDIAC CONSTRUCTS BY DYNAMIC CULTURE AND POROUS SCAFFOLDS}

Given the positive effect of dynamic culture conditions on cardiac gene activation, we sought to obtain vascularized cardiac 3D tissues by co-culturing hMSCs-derived vascular cells and pre-differentiated hCMPCs in the bioreactor system for 7 days, as described in Figure 6A. Gelatin sponges were first seeded with hMSCs under endothelial differentiation conditions. In the meantime, cTNT-GFP hCMPCs seeded on TCPS were challenged with CDM for 2 weeks, seeded onto hMSCs-loaded scaffolds and allowed to adhere for $24 \mathrm{~h}$ before being exposed to continuous medium flow. The analysis of the co-cultured constructs after 1 week testified massive scaffold colonization by the cells (Figure 6B). The scaffold thickness was not significantly modified by medium perfusion (data not shown) that affected, instead, cell migration inside the scaffold. In fact, the side of the colonized scaffolds directly exposed to flow showed a more uniform and extensive distribution of vascular-like cells (in red) and hCMPCderived cardiomyocytes (green) inside the scaffold, while the cells were mostly distributed on the scaffold surface in the static control (Figure 6C). The expression of VCAM-1 and CD144 endothelial markers confirmed the presence of endothelial-like cells, while GFP expression testified the persistence of a number of cardiac-like cells within the bio-construct (Figure 6D). Sections from the perfusion group showed VCAM-1-positive cells aligned forming tube-like structures around the pores and contacting GFP-positive cells (Figure 6E). The extensive cell distribution within the scaffold accounted for the formation of a densely packed multicellular tissue derived from the two different stem cell types used (Figure 6F).

\section{DISCUSSION}

Rebuilding functional portions of the myocardium requires the generation of bio-substitutes that best recapitulate the structure and function of the healthy myocardium, thus providing new cardiomyocytes with a functional vascular network, which may prevent or reduce pathological decline and improve cardiac function after injury (Simons and Ware, 2003; Kang et al., 2013). Exploiting cell sheet technology, our group and others successfully achieved the preparation of 3D cardiac tissues in the absence of scaffolds by different cell types having a cardiac significance (Haraguchi et al., 2006; Forte et al., 2011; Matsuura et al., 2012; Sekine et al., 2013). Nonetheless, the scaling up of solid engineered tissues to obtain a critical size substitute with therapeutical relevance is limited by the diffusion of oxygen, nutrients and waste products to and from the inner portion of the construct, impairing the survival of the newly formed tissue. In this 


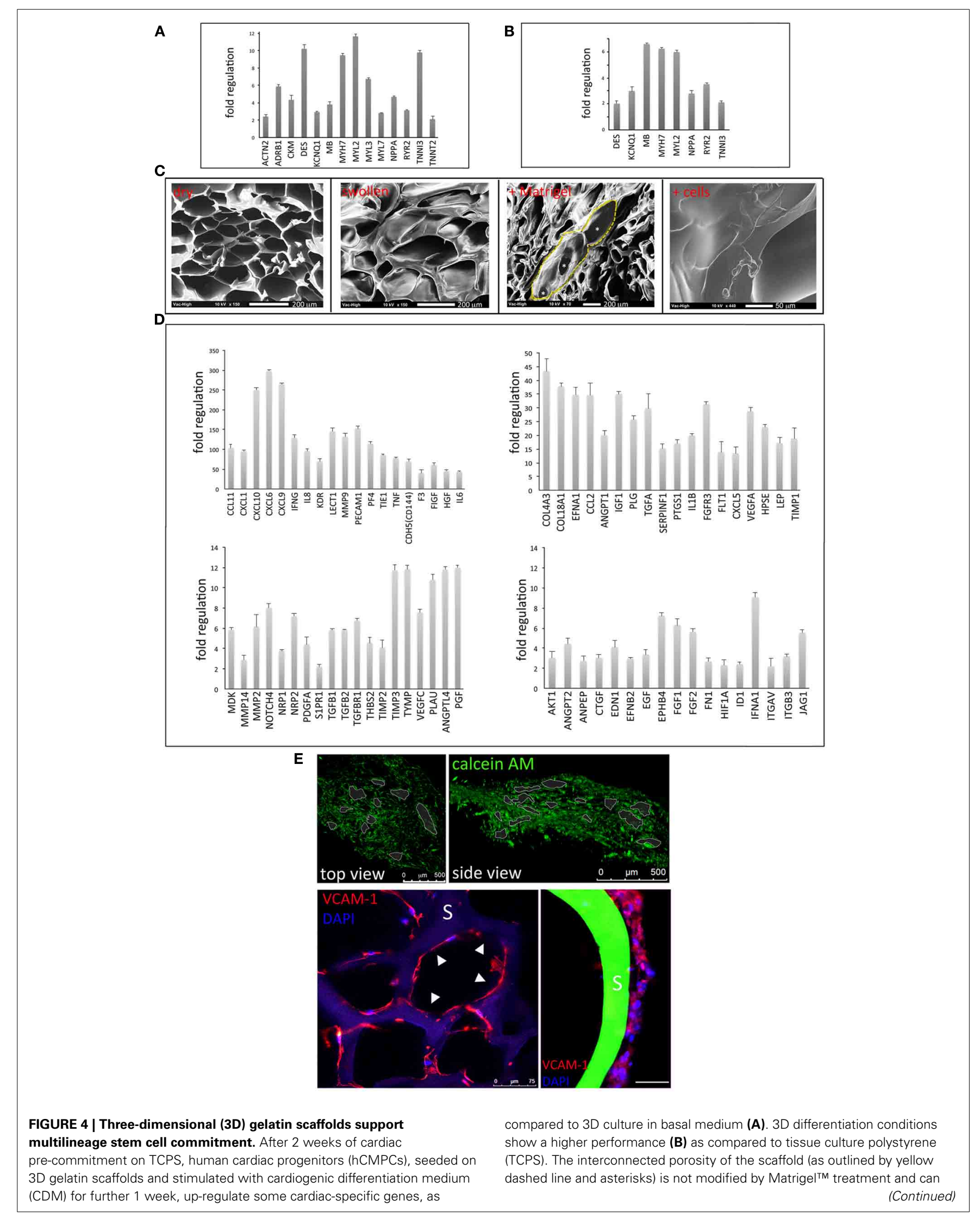




\section{FIGURE 4 | Continued}

accommodate human cells (C). Human mesenchymal stem cells (hMSCs) are differentiated to endothelial cells on 3D gelatin scaffolds when stimulated with endothelial differentiation medium (EDM) and low concentration of Matrige $\mathrm{I}^{\mathrm{TM}}$, as demonstrated by the upregulation of several vascular genes as analyzed by real time PCR (D). Calcein AM staining shows the network of living cells spreading throughout the scaffold (E, upper panels). Scaffold (S) pores are covered by lining cells expressing VCAM-1 as highlighted by white arrowheads ( $\mathbf{E}$, lower panel). A magnification of a cord-like structure aligned along a pore is visible on the right; scale bar: $100 \mu \mathrm{m}$.

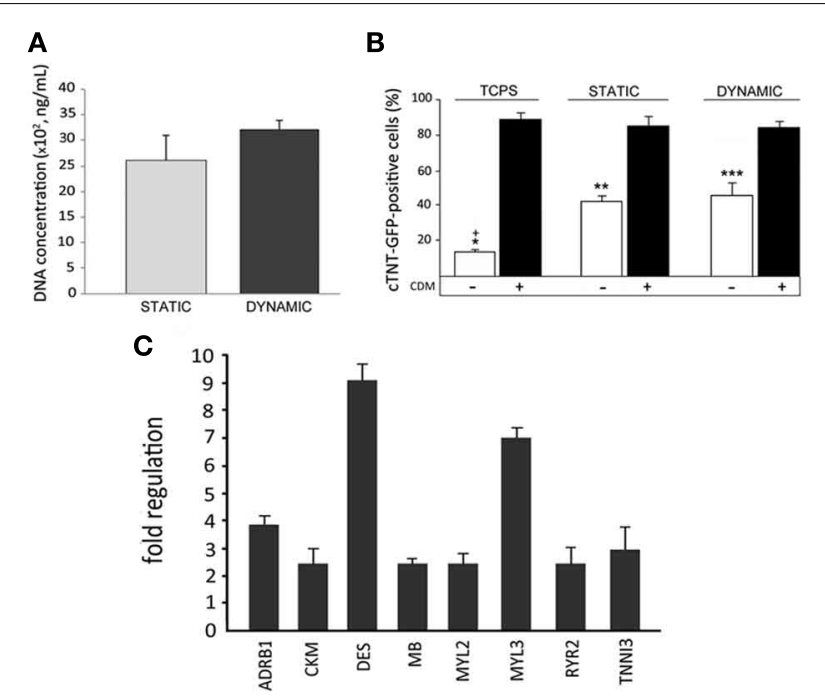

FIGURE 5 | Dynamic culture conditions induce a superior cardiac commitment in human cardiac progenitors (hCMPCs). Dynamic culture conditions provide a higher, although not significant, increase in scaffold cell colonization as compared to static conditions (A). Percentage of differentiated cTNT-GFP CMPCs stimulated with cardiogenic differentiation medium (CDM) and cultured on TCPS and scaffolds, under dynamic, or static conditions, as evidenced by FACS analysis (B) $\left(^{*}, * *, * * * P<0.05\right.$ between hCMPC basal medium and CDM). Importantly, a significant commitment can be induced, equivalently, by $3 D$ culture itself in both static and dynamic conditions compared to TCPS ${ }^{+} P<0.05$ between TCPS and 3D scaffolds). Nonetheless, quantitative PCR analysis demonstrates the up-regulation of few cardiac-specific genes in hCMPCs (C) cultured in dynamic conditions, as compared to its static control (for a complete list of genes analyzed please refer to Supplementary Table 1; among the genes analyzed, those not showing a consistent and significant difference in the expression as compared to their respective controls, are not shown).

context, the use of porous scaffolds to generate in vitro artificial bio-substitutes gives the opportunity to choose the shape and the size of the graft, while second-generation scaffolds are currently proposed as active templates which can be removed in a timely fashion compatible with tissue growth and exert an instructive role in the formation of the new tissue (Forte et al., 2013; Pagliari et al., 2013). In the present study, we propose a multistep procedure to prepare adult stem cell-derived prevascularized thick cardiac patches by using $3 \mathrm{D}$ porous gelatin scaffolds and dynamic culture conditions. The procedure here adopted is based on the peculiar differentiation potential of two different autologous adult cell subsets, mesenchymal, and cardiac resident stem cells. Human MSCs can be routinely obtained from patient bone marrow and display a minimal, if any, ability to give raise to cardiomyocytes (Gnecchi et al., 2005; Loffredo et al., 2011), while they are supposed to retain an intrinsic vascular potential (Oswald et al., 2004). In the present investigation,
hMSCs were efficiently driven to acquire an endothelial phenotype by means of EDM in 3D culture conditions. In particular, when grown on $3 \mathrm{D}$ porous gelatin scaffold, hMSCs showed a robust vascular commitment as confirmed by the up-regulation of 73 genes involved in angiogenesis. Among these, angiopoietin 1 (ANGPT1), which has been shown to promote blood vessel maturation by regulating endothelial cell survival and the recruitment of mural cells (Thomas and Augustin, 2009), encountered a 20 -fold increase, thus suggesting stability of the newly formed vascular network. At the same time, CPCs can be extracted from patient atrial biopsies and are known to possess the potential to generate new cardiomyocytes in vitro and in vivo (Beltrami et al., 2003; Goumans et al., 2007) making them an effective and safe cardiogenic cell type (Bolli et al., 2011; Makkar et al., 2012). In the present investigation, we explored the possibility to generate a $3 \mathrm{D}$ cardiac tissue in vitro by pre-committed hCMPCs. Although most of the attempts to regenerate damaged myocardium have used undifferentiated cells, concerns have been raised due to the poor differentiation capability of adult progenitors in vivo, together with the potential of pluripotent stem cells to give birth to undesired phenotypes. Recently, it has been suggested that the transplantation of pre-committed cells could improve the clinical outcome in cardiac patients (Heng et al., 2004; Mehta and Shim, 2013). For this reason, stem/progenitor cells were appropriately stimulated to undergo tissue specific pre-commitment before being used for all co-culture experiments. However, given that the mechanical properties of the gelatin scaffolds used here are similar to those of cardiac tissue, a spontaneous commitment of cardiac progenitor cells could be obtained through 3D culture per $s e$, as demonstrated by the increased percentage of GFP-positive cells and similarly to what we and others previously demonstrated (Engler et al., 2006; Pagliari et al., 2011; Gaetani et al., 2012; Mosqueira et al., 2014). However, despite the fact that the gene expression profile analysis confirmed a moderate commitment of hCMPCs induced by the scaffold itself, biological factors were needed to improve this effect. In particular, when cells seeded on the scaffold were stimulated with CDM, we observed an increased expression of cardiac troponin genes (TNNT2, 3) along with the up-regulation of ryanodine receptor 2 (RYR2, involved in muscle excitation-contraction coupling, Bround et al., 2012) and natriuretic peptide precursor A (NPPA) genes. These data suggest that the combination of $3 \mathrm{D}$ porous gelatin and CDM represents a suitable combination to provide cells with biological and mechanical signals synergistically supporting the commitment of hCMCPs at a later stage. Nonetheless, neither complete sarcomeric structures nor any beating activity could be noticed in prompted cells. This evidence suggested that the system implemented represents a good tool to induce an efficient cardiac commitment and study the behavior of late cardiac progenitors, but this also implicates that more complex devices providing stretching and/or electrical 


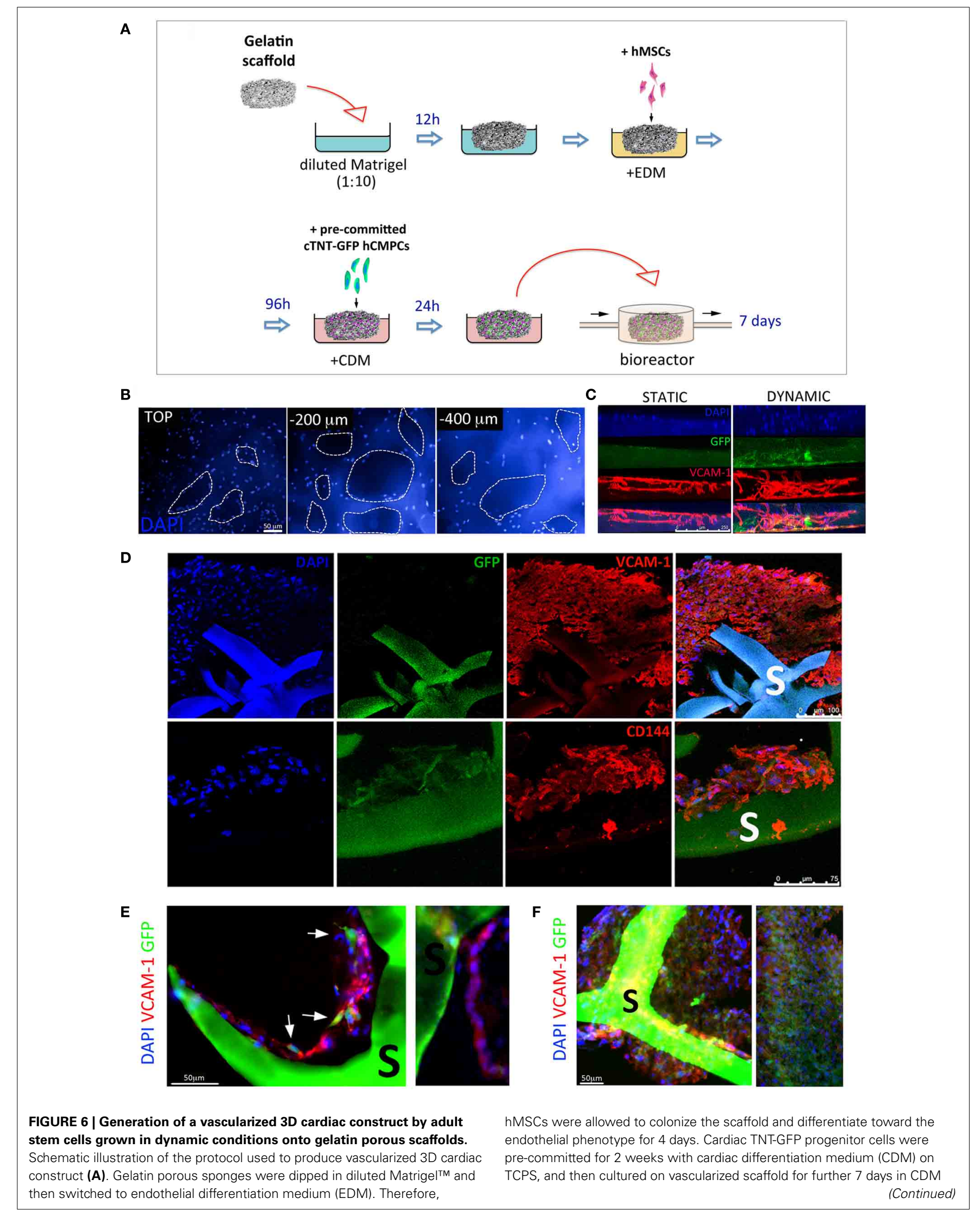




\section{FIGURE 6 | Continued}

and in a perfusive modular bioreactor. Human cells colonize the scaffold inner layers as shown by nuclei staining at different depths (B). Side view of cellularized scaffolds cultured under static or dynamic conditions (C); infiltration of GFP- (cardiomyocyte-like cells, green) and VCAM-1-positive cells (endothelial-like cells, red) into scaffold is improved by dynamic culture. Immunohistochemistry analysis of the colonized scaffolds shows the massive infiltration of VCAM-1, CD144 cells in the core of the construct. Higher magnification images (D) shows the VCAM-1-positive cells aligned in tube-like structures around the pores and contacting GFP-positive cells (E,F). S, scaffold stimulation are probably necessary to deliver more specific stimuli and improve the outcome in terms of cardiac differentiation. The activation of genes involved in matrix remodeling observed in $3 \mathrm{D}$ testified the ability of cells to actively interact with the natural support they grow on. In fact, while the up-regulation of Matrix metalloproteinase (MMP) genes and their regulators, tissue inhibitors of metalloproteinase (TIMP), is predictive of gelatin remodeling and breakdown, the activation of genes encoding for different collagens and laminins suggest the concomitant substitution of the artificial matrix with neo-formed tissue.

Bioreactors have been widely proposed to intensify oxygen and nutrient transport and increase the viability and function of thick cardiovascular tissue-engineered substitutes (Zimmermann et al., 2006; Cimetta et al., 2007; Burdick and Vunjak-Novakovic, 2009). In our experimental setting, dynamic culture conditions positively affected cardiac commitment, leading to a significant increase in GFP-expressing cells as compared to TCPS and independently of biological stimulation. Since the increase in GFP was not significantly different from that observed under 3D static culture conditions, it might be concluded that providing cells with continuous medium flow does not positively affect on cardiac progenitor differentiation potential on the scaffold. Nevertheless, the expression of genes recognized to be essential for the formation or regulation of the contractile apparatus was positively influenced when dynamic flow was applied to cells grown in a 3D environment. Hence, the use of a modular bioreactor providing continuous media turnover to the scaffold resulted in a superior performance in terms of cardiac gene activation. In the light of these promising results, we also expected that direct perfusion of cells could promote the formation of a vascularized cardiac patch. In line with previous descriptions (Maidhof et al., 2012), we observed more uniform and dense spatial cell distribution in the scaffold, with cells migrating toward the substrate inner core under dynamic conditions. Thus we established a method for sequential cell seeding: gelatin scaffolds were colonized with hMSCs and maintained in static conditions for 4 days in order to favor the endothelialization of the substrate, then scaffolds were loaded with pre-committed GFP-positive cardiac progenitors and cultured in perfusion bioreactor for 1 week in the presence of cardiogenic medium. As a result, a 3D cardiac proto-tissue composed of densely packed cardiomyocyte-like cells intertwined with vessel-like structures was obtained. Although being promising in terms of cell colonization and survival, these co-culture conditions did not yield the formation of functional contractile and vascular structures. Thus additional experiments will be necessary to provide cells with other cues in vitro to complete the organization of a proper vascularized cardiac tissue.

Nonetheless, irrespective of the stem cell subsets used, the procedure here described provides a novel platform for the preparation of complex $3 \mathrm{D}$ vascularized bio-constructs to be used for in vitro studies aiming at the understanding of stem cell behavior in a more physiological context. Pre-clinical animal studies addressing the long-term in vivo survival and the relevance of the constructs will be necessary before this technique may represent a suitable platform for future clinical applications.

\section{ACKNOWLEDGMENTS}

The present work was supported by the Japan Society for the Promotion of Science (JSPS) through the "Funding Program for World-Leading Innovative R\&D on Science and Technology (FIRST Program)" and the World Premier International (WPI) Research Center Initiative. Stefania Pagliari was supported by JSPS fellowship; Marie-Josè Goumans was supported by Netherlands Institute for Regenerative Medicine (NIRM) and Giancarlo Forte by the European Regional Development FundProject FNUSA-ICRC (No. CZ.1.05/1.1.00/02.0123).

\section{SUPPLEMENTARY MATERIAL}

The Supplementary Material for this article can be found online at: http://www.frontiersin.org/journal/10.3389/fphys.2014. 00210/abstract

\section{REFERENCES}

Abramoff, M. D., Magalhaes, P. J., and Ram, S. J. (2004). Image processing with ImageJ. Biophoton. Int. 11, 36-42.

Akhyari, P., Fedak, P. W., Weisel, R. D., Lee, T. Y., Verma, S., Mickle, D. A., et al. (2002). Mechanical stretch regimen enhances the formation of bioengineered autologous cardiac muscle grafts. Circulation 106, I137-I142. doi: 10.1161/01.cir.0000032893.55215.fc

Bai, K., Huang, Y., Jia, X., Fan, Y., and Wang, W. (2010). Endothelium oriented differentiation of bone marrow mesenchymal stem cells under chemical and mechanical stimulations. J. Biomech. 43, 1176-1181. doi: 10.1016/j.jbiomech.2009.11.030

Beltrami, A. P., Barlucchi, L., Torella, D., Baker, M., Limana, F., Chimenti, S., et al. (2003). Adult cardiac stem cells are multipotent and support myocardial regeneration. Cell 114, 763-776. doi: 10.1016/S0092-8674(03) 00687-1

Bolli, R., Chugh, A. R., D’Amario, D., Loughran, J. H., Stoddard, M. F., Ikram, S., et al. (2011). Cardiac stem cells in patients with ischaemic cardiomyopathy (SCIPIO): initial results of a randomised phase 1 trial. Lancet 378, 1847-1857. doi: 10.1016/S0140-6736(11)61590-0

Boschetti, F., Raimondi, M. T., Migliavacca, F., and Dubini, G. (2006). Prediction of the micro-fluid dynamic environment imposed to threedimensional engineered cell systems in bioreactors. J. Biomech. 39, 418-425. doi: 10.1016/j.jbiomech.2004.12.022

Brannon-Peppas, L., and Peppas, N. A. (1990). Dynamic and equilibrium swelling behaviour of $\mathrm{pH}$-sensitive hydrogels containing 2-hydroxyethyl methacrylate. Biomaterials 11, 635-644.

Bround, M. J., Asghari, P., Wambolt, R. B., Bohunek, L., Smits, C., Philit, M., et al. (2012). Cardiac ryanodine receptors control heart rate and rhythmicity in adult mice. Cardiovasc. Res. 96, 372-380. doi: 10.1093/cvr/cvs260

Burdick, J. A., and Vunjak-Novakovic, G. (2009). Engineered microenvironments for controlled stem cell differentiation. Tissue Eng. Part A 15, 205-219. doi: 10.1089/ten.tea.2008.0131

Caspi, O., Lesman, A., Basevitch, Y., Gepstein, A., Arbel, G., Habib, I. H., et al. (2007). Tissue engineering of vascularized cardiac muscle from human 
embryonic stem cells. Circ. Res. 100, 263-272. doi: 10.1161/01.RES.0000257776. 05673.ff

Chiu, L. L., and Radisic, M. (2010). Scaffolds with covalently immobilized VEGF and angiopoietin-1 for vascularization of engineered tissues. Biomaterials 31, 226-241. doi: 10.1016/j.biomaterials.2009.09.039

Cimetta, E., Flaibani, M., Mella, M., Serena, E., Boldrin, L., De Coppi, P., et al. (2007). Enhancement of viability of muscle precursor cells on 3D scaffold in a perfusion bioreactor. Int. J. Artif. Organs 30, 415-428.

Cipolleschi, M. G., Dello Sbarba, P., and Olivotto, M. (1993). The role of hypoxia in the maintenance of hematopoietic stem cells. Blood 82, 2031-2037.

Dreesmann, L., Ahlers, M., and Schlosshauera, B. (2007). The pro-angiogenic characteristics of a cross-linked gelatin matrix. Biomaterials 28, 5536-5543. doi: 10.1016/j.biomaterials.2007.08.040

Dubois, C., Liu, X., Claus, P., Marsboom, G., Pokreisz, P., Vandenwijngaert, S., et al. (2010). Differential effects of progenitor cell populations on left ventricular remodeling and myocardial neovascularization after myocardial infarction. J. Am. Coll. Cardiol. 55, 2232-2243. doi: 10.1016/j.jacc.2009.10.081

Dvir, T., Kedem, A., Ruvinov, E., Levy, O., Freeman, I., Landa, N., et al. (2009). Prevascularization of cardiac patch on the omentum improves its therapeutic outcome. Proc. Natl. Acad. Sci. U.S.A. 106, 14990-14995. doi: 10.1073/pnas.0812242106

Engler, A. J., Rehfeldt, F., Sen, S., and Discher, D. E. (2007). Microtissue elasticity: measurements by atomic force microscopy and its influence on cell differentiation. Methods Cell Biol. 83, 521-545. doi: 10.1016/S0091-679X(07)83022-6

Engler, A. J., Sen, S., Sweeney, H. L., and Discher, D. E. (2006). Matrix elasticity directs stem cell lineage specification. Cell 126, 677-689. doi: 10.1016/j.cell.2006.06.044

Forte, G., Pagliari, S., Pagliari, F., Ebara, M., Di Nardo, P., and Aoyagi, T. (2013). Towards the generation of patient-specific patches for cardiac repair. Stem Cell Rev. 9, 313-325. doi: 10.1007/s12015-011-9325-8

Forte, G., Pietronave, S., Nardone, G., Zamperone, A., Magnani, E., Pagliari, S., et al. (2011). Human cardiac progenitor cell grafts as unrestricted source of super-numerary cardiac cells in healthy murine hearts. Stem Cells 29, 2051-2061. doi: 10.1002/stem.763

Gaetani, R., Doevendans, P. A., Metz, C. H., Alblas, J., Messina, E., Giacomello, A., et al. (2012). Cardiac tissue engineering using tissue printing technology and human cardiac progenitor cells. Biomaterials 33, 1782-1790. doi: 10.1016/j.biomaterials.2011.11.003

Gnecchi, M., He, H., Liang, O. D., Melo, L. G., Morello, F., Mu, H., et al. (2005). Paracrine action accounts for marked protection of ischemic heart by Akt-modified mesenchymal stem cells. Nat. Med. 11, 367-368. doi: 10.1038/nm0405-367

Gnecchi, M., Zhang, Z., Ni, A., and Dzau, V. J. (2008). Paracrine mechanisms in adult stem cell signaling and therapy. Circ. Res. 103, 1204-1219. doi: 10.1161/CIRCRESAHA.108.176826

Goumans, M. J., de Boer, T. P., Smits, A. M., van Laake, L. W., van Vliet, P., Metz, C. H., et al. (2007). TGF-betal induces efficient differentiation of human cardiomyocyte progenitor cells into functional cardiomyocytes in vitro. Stem Cell Res. 1, 138-149. doi: 10.1016/j.scr.2008.02.003

Haraguchi, Y., Shimizu, T., Yamato, M., Kikuchi, A., and Okano, T. (2006). Electrical coupling of cardiomyocyte sheets occurs rapidly via functional gap junction formation. Biomaterials 27, 4765-4774. doi: 10.1016/j.biomaterials.2006.04.034

Heng, B. C., Haider, H. Kh., Sim, E. K., Cao, T., and Ng, S. C. (2004). Strategies for directing the differentiation of stem cells into the cardiomyogenic lineage in vitro. Cardiovasc. Res. 62, 34-42. doi: 10.1016/j.cardiores.2003. 12.022

Jazayeri, M., Allameh, A., Soleimani, M., Jazayeri, S. H., Piryaei, A., and Kazemnejad, S. (2008). Molecular and ultrastructural characterization of endothelial cells differentiated from human bone marrow mesenchymal stem cells. Cell Biol. Int. 32, 1183-1192. doi: 10.1016/j.cellbi.2008.07.020

Kang, K. T., Coggins, M., Xiao, C., Rosenzweig, A., and Bischoff, J. (2013). Human vasculogenic cells form functional blood vessels and mitigate adverse remodeling after ischemia reperfusion injury in rats. Angiogenesis 16, 773-784. doi: 10.1007/s10456-013-9354-9

Lalu, M. M., McIntyre, L., Pugliese, C., Fergusson, D., Winston, B. W., Marshall, J. C., et al. (2012). Safety of cell therapy with mesenchymal stromal cells (SafeCell): a systematic review and meta-analysis of clinical trials. PLoS ONE 7:e47559. doi: 10.1371/journal.pone.0047559
Levenberg, S., Rouwkema, J., Macdonald, M., Garfein, E. S., Kohane, D. S., Darland, D. C., et al. (2005). Engineering vascularized skeletal muscle tissue. Nat. Biotechnol. 23, 879-884. doi: 10.1038/nbt1109

Lian, F., Xue, S., Gu, P., and Zhu, H. S. (2008). The long-term effect of autologous endothelial progenitor cells from peripheral blood implantation on infarcted myocardial contractile force. J. Int. Med. Res. 36, 40-46. doi: $10.1177 / 147323000803600106$

Lien, S. M., Ko, L. Y., and Huang, T. J. (2009). Effect of pore size and ECM secretion and cell growth in gelatin scaffold for articular cartilage tissue engineering. Acta Biomater. 5, 670-679. doi: 10.1016/j.actbio.2008.09.020

Loffredo, F. S., Steinhauser, M. L., Gannon, J., and Lee, R. T. (2011). Bone marrowderived cell therapy stimulates endogenous cardiomyocyte progenitors and promotes cardiac repair. Cell Stem Cell 8, 389-398. doi: 10.1016/j.stem.2011. 02.002

Lovett, M., Lee, K., Edwards, A., and Kaplan, D. L. (2009). Vascularization strategies for tissue engineering. Tissue Eng. Part B Rev. 15, 353-370. doi: 10.1089/ten.TEB.2009.0085

Lozito, T. P., Kuo, C. K., Taboas, J. M., and Tuan, R. S. (2009). Human mesenchymal stem cells express vascular cell phenotypes upon interaction with endothelial cell matrix. J. Cell. Biochem. 107, 714-722. doi: 10.1002/jcb.22167

Maidhof, R., Tandon, N., Lee, E. J., Luo, J., Duan, Y., Yeager, K., et al. (2012). Biomimetic perfusion and electrical stimulation applied in concert improved the assembly of engineered cardiac tissue. J. Tissue Eng. Regen. Med. 6, e12-e23. doi: 10.1002/term.525

Makkar, R. R., Smith, R. R., Cheng, K., Malliaras, K., Thomson, L. E., Berman, D., et al. (2012). Intracoronary cardiosphere-derived cells for heart regeneration after myocardial infarction (CADUCEUS): a prospective, randomised phase 1 trial. Lancet 379, 895-904. doi: 10.1016/S0140-6736(12)60195-0

Martucci, J. F., Ruseckaite, R. A., and Vàzquez, A. (2006). Creep of glutaraldehydecrosslinked gelatin films. Mater. Sci. Eng. A 435-436, 681-686. doi: 10.1016/j.msea.2006.07.097

Matsuura, K., Wada, M., Konishi, K., Sato, M., Iwamoto, U., Sato, Y., et al. (2012). Fabrication of mouse embryonic stem cell-derived layered cardiac cell sheets using a bioreactor culture system. PLoS ONE 7:e52176. doi: 10.1371/journal.pone.0052176

Mazzei, D., Guzzardi, M. A., Giusti, S., and Ahluwalia, A. (2010). A low shear stress modular bioreactor for connected cell culture under high flow rates. Biotechnol. Bioeng. 106, 127-137. doi: 10.1002/bit.22671

Mehta, A., and Shim, W. (2013). Cardiac stem cell therapy: stemness or commitment? Cell Transplant. 22, 1-14. doi: 10.3727/096368912X653282

Menasche, P. (2011). Cardiac cell therapy: lessons from clinical trials. J. Mol. Cell. Cardiol. 50, 258-265. doi: 10.1016/j.yjmcc.2010.06.010

Meyer, G. P., Wollert, K. C., Lotz, J., Pirr, J., Rager, U., Lippolt, P., et al. (2009). Intracoronary bone marrow cell transfer after myocardial infarction: 5-year follow-up from the randomized-controlled BOOST trial. Eur. Heart J. 30, 2978-2984. doi: 10.1093/eurheartj/ehp374

Mosqueira, D., Pagliari, S., Uto, K., Ebara, M., Romanazzo, S., Escobedo-Lucea, C., et al. (2014). Hippo pathway effectors control cardiac progenitor cell fate by acting as dynamic sensors of substrate mechanics and nanostructure. ACS Nano 8, 2033-2047. doi: 10.1021/nn4058984

Muraglia, A., Cancedda, R., and Quarto, R. (2000). Clonal mesenchymal progenitors from human bone marrow differentiate in vitro according to a hierarchical model. J. Cell Sci. 113, 1161-1166.

Mwangi, J. W., and Ofner, C. M. 3rd (2004). Crosslinked gelatin matrices: release of a random coil macromolecular solute. Int. J. Pharm. 278, 319-327. doi: 10.1016/j.ijpharm.2004.03.024

Oswald, J., Boxberger, S., Jorgensen, B., Feldmann, S., Ehninger, G., Bornhauser, M., et al. (2004). Mesenchymal stem cells can be differentiated into endothelial cells in vitro. Stem Cells 22, 377-384. doi: 10.1634/stemcells.22-3-377

Pagliari, S., Romanazzo, S., Mosqueira, D., Pinto-do-Ó, P., Aoyagi, T., and Forte, G. (2013). Adult stem cells and biocompatible scaffolds as powerful drug delivery tools for cardiac repair. Curr. Med. Chem. 20, 3429-3447. doi: 10.2174/09298673113209990032

Pagliari, S., Vilela-Silva, A. C., Forte, G., Pagliari, F., Mandoli, C., Vozzi, G., et al. (2011). Cooperation of biological and mechanical signals in cardiac progenitor cell differentiation. Adv. Mater. 23, 514-518. doi: 10.1002/adma.201003479

Pampaloni, F., Reynaud, E. G., and, Stelzer, E. H. (2007). The third dimension bridges between cell culture and live tissue. Nat. Rev. Mol. Cell Biol. 8, 839-845. doi: $10.1038 / \mathrm{nrm} 2236$ 
Pittenger, M. F., Mackay, A. M., Beck, S. C., Jaiswal, R. K., Douglas, R., Mosca, J. D., et al. (1999). Multilineage potential of adult human mesenchymal stem cells. Science 284,143-147. doi: 10.1126/science.284.5411.143

Portalska, K. J., Leferink, A., Groen, N., Fernandes, H., Moroni, L., van Blitterswijk, C., et al. (2012). Endothelial differentiation of mesenchymal stromal cells. PLoS ONE 7:e46842. doi: 10.1371/journal.pone.0046842

Sakaguchi, K., Shimizu, T., Haraguchi, S., Sekine, H., Yamato, M., Umezu, M., et al. (2013). In vitro engineering of vascularized tissue surrogates. Sci. Rep. 3:1316. doi: $10.1038 /$ srep01316

Sakai, T., Li, R. K., Weisel, R. D., Mickle, D. A., Kim, E. T., Jia, Z. Q., et al. (2001). The fate of a tissue-engineered cardiac graft in the right ventricular outflow tract of the rat. J. Thorac. Cardiovasc. Surg. 121, 932-942. doi: $10.1067 / \mathrm{mtc} .2001 .113600$

Sato, K., Wu, T., Laham, R. J., Johnson, R. B., Douglas, P., Li, J., et al. (2001). Efficacy of intracoronary or intravenous VEGF165 in a pig model of chronic myocardial ischemia. J. Am. Coll. Cardiol. 37, 616-623. doi: 10.1016/S0735-1097(00) 01144-X

Segers, V. F. M., and Lee, R. T. (2011). Biomaterials to enhance stem cell function in the heart. Circ. Res. 109, 910-922. doi: 10.1161/CIRCRESAHA.111.249052

Sekine, H., Shimizu, T., Sakaguchi, K., Dobashi, I., Wada, M., Yamato, M., et al. (2013). In vitro fabrication of functional three-dimensional tissues with perfusable blood vessels. Nat. Commun. 4:1399. doi: 10.1038/ ncomms 2406

Simons, M., and Ware, J. A. (2003). Therapeutic angiogenesis in cardiovascular disease. Nat. Rev. Drug Discov. 2, 863-871. doi: 10.1038/nrd1226

Simón-Yarza, T., Formiga, F. R., Tamayo, E., Pelacho, B., Prosper, F., and BlancoPrieto, M. J. (2012). Vascular endothelial growth factor-delivery systems for cardiac repair: an overview. Theranostics 2, 541-552. doi: 10.7150/thno.3682

Singh, S., Wu, B. M., and Dunn, J. C. (2012). Delivery of VEGF using collagencoated polycaprolactone scaffolds stimulates angiogenesis. J. Biomed. Mater. Res. 100, 720-727. doi: 10.1002/jbm.a.34010

Smits, A. M., van Laake, L. W., den Ouden, K., Schreurs, C., Szuhai, K., van Echteld, C. J., et al. (2009a). Human cardiomyocyte progenitor cell transplantation preserves long-term function of the infarcted mouse myocardium. Cardiovasc. Res. 83, 527-535. doi: 10.1093/cvr/cvp146

Smits, A. M., van Vliet, P., Metz, C. H., Korfage, T., Sluijter, J. P., Doevendans, P. A., et al. (2009b). Human cardiomyocyte progenitor cells differentiate into functional mature cardiomyocytes: an in vitro model for studying human cardiac physiology and pathophysiology. Nat. Protoc. 4, 232-243. doi: 10.1038/nprot.2008.229

Spinelli, A., Vinci, B., Tirella, A., Matteucci, M., Gargani, L., Ahluwalia, A., et al. (2012). Realization of a poro-elastic ultrasound replica of pulmonary tissue. Biomatter 2, 37-42. doi: 10.4161/biom.19835

Terrovitis, J. V., Smith, R. R., and Marbán, E. (2010). Assessment and optimization of cell engraftment after transplantation into the heart Circ. Res. 106, 479-494. doi: 10.1161/CIRCRESAHA.109.208991
Thomas, M., and Augustin, H. G. (2009). The role of the Angiopoietins in vascular morphogenesis. Angiogenesis 12, 125-137. doi: 10.1007/s10456-009-9147-3

Urbich, C., Heeschen, C., Aicher, A., Sasaki, K., Bruhl, T., Farhadi, M. R., et al. (2005). Cathepsin $\mathrm{L}$ is required for endothelial progenitor cell-induced neovascularization. Nat. Med. 11, 206-213. doi: 10.1038/nm1182

Varum, S., Rodrigues, A. S., Moura, M. B., Momcilovic, O., Easley, C. A. 4th, Ramalho-Santos, J., et al. (2011). Energy metabolism in human pluripotent stem cells and their differentiated counterparts. PLoS ONE 6:e20914. doi: 10.1371/journal.pone.0020914

Vozzi, F., Mazzei, D., Vinci, B., Vozzi, G., Sbrana, T., Ricotti, L., et al. (2011). A flexible bioreactor system for constructing in vitro tissue and organ models. Biotechnol. Bioeng. 108, 2129-2140. doi: 10.1002/bit.23164

Wang, D. M., and Tarbell, J. M. (1995). Modeling interstitial flow in an artery wall allows estimation of wall shear stress on smooth muscle cells. J. Biomech. Eng. $117,358-366$.

Wöhrle, J., Merkle, N., Mailänder, V., Nusser, T., Schauwecker, P., von Scheidt, F., et al. (2010). Results of intracoronary stem cell therapy after acute myocardial infarction. Am. J. Cardiol. 105, 804-812. doi: 10.1016/j.amjcard.2009.10.060

Wu, S. C., Chang, W. H., Dong, C. G., Chen, K. Y., Chen, Y. S., and Yao, C. H. (2011). Cell adhesion and proliferation enhancement by gelatin nanofiber scaffolds. J. Bioact. Compat. Polym. 26, 565-577. doi: 10.1177/0883911511423563

Xing, Q., Yates, K., Vogt, C., Qian, Z., Frost, M. C., and Zhao, F. (2014). Increasing mechanical strength of gelatin hydrogels by divalent metal ion removal. Sci. Rep. 4:4706. doi: 10.1038/srep04706

Zimmermann, W. H., Melnychenko, I., Wasmeier, G., Didié, M., Naito, H., Nixdorff, U., et al. (2006). Engineered heart tissue grafts improve systolic and diastolic function in infarcted rat hearts. Nat. Med. 12, 452-458. doi: $10.1038 / \mathrm{nm} 1394$

Conflict of Interest Statement: The authors declare that the research was conducted in the absence of any commercial or financial relationships that could be construed as a potential conflict of interest.

Received: 21 March 2014; accepted: 15 May 2014; published online: 03 June 2014. Citation: Pagliari S, Tirella A, Ahluwalia A, Duim S, Goumans M-J, Aoyagi T and Forte $G$ (2014) A multistep procedure to prepare pre-vascularized cardiac tissue constructs using adult stem sells, dynamic cell cultures, and porous scaffolds. Front. Physiol. 5:210. doi: 10.3389/fphys.2014.00210

This article was submitted to Striated Muscle Physiology, a section of the journal Frontiers in Physiology.

Copyright (C) 2014 Pagliari, Tirella, Ahluwalia, Duim, Goumans, Aoyagi and Forte. This is an open-access article distributed under the terms of the Creative Commons Attribution License (CC BY). The use, distribution or reproduction in other forums is permitted, provided the original author(s) or licensor are credited and that the original publication in this journal is cited, in accordance with accepted academic practice. No use, distribution or reproduction is permitted which does not comply with these terms. 